\section{The defense industry in an age of austerity}

\section{Ron Smith}

$\mathrm{E}$ ven without the U.S. budget battles, with their fiscal cliffs and sequestration, deficit-reduction pressures and withdrawal from Afghanistan would have constrained future U.S. military expenditure, just as austerity constrains European military expenditure. Reductions in military expenditure will generate pressures to restructure the defense industry. The proposed merger of BAE Systems and EADS, announced in September 2012 and killed by German government opposition a month later, is an early indication of such pressures. While history does not repeat itself, it may be informative to examine an earlier period of restructuring, between the end of the cold war in 1990 and the beginning of the "war on terror" in 2001, to see what we might expect in response to future cuts. The structure of the industry at the end of the cold war is reviewed in Smith (1990) and just before the "war on terror" in Smith (2001). Hartley (2007) and Brauer (2007) have more general discussions of the industry.

While reductions in U.S. and European military expenditure are likely, they are not inevitable and the actual course of future military expenditure will depend on future security scenarios. There are many flash points which might erupt into conflict driving up military spending. These include the Middle East, India-Pakistan, and, in East Asia, North Korea and China's territorial disputes with many of its neighbors. Nonetheless, this note explores the implications for industrial structure of a more peaceful evolution of military expenditure.

World military expenditure peaked in the mid-1980s, started to fall gently at first and then rapidly after the dissolution of the Soviet Union, before rising again in the first decade of the 21st century with the invasions of Afghanistan and Iraq. SIPRI estimates that world military expenditure, measured in 2010 prices, was US $\$ 1,511$ billion in 1988 and fell to \$994bn in 1998. By 2011, it rose again to \$1,625bn, with the U.S. responsible for a 42 percent share.

The arms trade showed similar trends. The SIPRI trend indicator value for arms exports, measured in 1990 prices, was \$46bn in 1982, fell to \$18bn in 2002, and rose to almost $\$ 30 \mathrm{bn}$ in 2011. The value of the arms trade is small relative to military expenditure, so arms exports are unlikely to be a solution to any reduction in demand that the industry faces. In the U.S., the U.K., and in some other countries the cuts in military expenditure after the cold war were associated with a long economic boom during the last decade of the twentieth century with lower interest rates, higher investment, and higher productivity growth. Brzoska (2007) provides a survey of defense conversion during the "long decade of disarmament" after the end of the cold war.

The trends in military expenditure and in arms exports were reflected in the output of the arms industry. SIPRI (2000, p. 315) estimated that arms production (domestic demand plus exports minus imports) in 1997 was only 56 percent of its 1987 level in the U.S., 77 percent in France, and 90 percent in the U.K. Arms sales by the top-100 companies in the SIPRI list measured in 2010 prices rose from $\$ 257 b$ in 2002 to $\$ 411$ bn in 2010, and then fell by 5 percent in 2011.

The U-shaped pattern in military expenditure was matched by an inverted U-shaped pattern in industry concentration. Dunne (2009) discusses the evolution of concentration in the arms industry, which at the end of the cold war was very low. The five largest companies in the SIPRI top-100 list accounted for almost 23 percent of arms sales in 1990. This is a low proportion by comparison with other high technology industries. During the 1990s falling demand, rising fixed costs, and a merger wave increased concentration, and by 1998, the five largest arms firms accounted for 45 percent of the total. Concentration then stabilized, and in 2003 it was 44 percent. However, increasing military expenditure during the following years diluted the concentration, and in 2010 the five largest arms firms accounted for 37 percent, falling further to 35 percent in 2011. One might expect that future cuts in military expenditure would cause concentration to stop falling and start rising again. Had BAE and EADS merged, the top- 5 firms would have accounted for 41 percent of sales, still below the 1998 share.

Of the 2010 total for the 100 largest arms firms, over half, \$250bn, was by U.S. companies and another quarter, $\$ 120 \mathrm{bn}$, by European countries. Of the European total, the U.K. accounted for \$50bn, France for \$23bn, the trans-European EADS (European Aeronautics, Defence and Space) for \$16bn, Italy for \$15bn, Germany for $\$ 7 \mathrm{bn}$, and other European countries for \$9bn. Among the top-20 arms companies on the SIPRI list for 2010, 13 are from the U.S. The largest U.S. companies and their arms sales are: Lockheed Martin (\$36bn), Boeing (\$31bn), Northrop Grumman (\$28bn), General Dynamics (\$24bn), and Raytheon (\$23bn). Of the remaining 7 companies, one is trans-European, EADS $(\$ 16 b n)$, two are from the U.K. (BAE systems, \$33bn, and Rolls Royce, \$4bn), one is Italian (Finmeccanica, \$14bn, and 30 percent owned by the Italian state), two are French (Thales, $\$ 10 \mathrm{bn}$, and 27 percent owned by the French state, and Safran, $\$ 5 b n$, and 30 percent owned by the French state), and one company is Russian (Almaz-Antei, \$4bn).

Faced with the reduction in military demand, these large arms firms have to 
consider their industrial options, such as to convert, diversify, divest, cooperate, or concentrate. Their strategic options are constrained by government regulation and by the nature of the financial systems within which they operate. We begin with regulation.

Regulation

The arms industry is inherently political and subject to state regulation. Many arms firms are wholly or partly state owned, but even when there is no state shareholding, governments can regulate them through their procurement policy-governments being the only buyers of major weapons systems. Governments regulate and promote arms exports, approve mergers and acquisitions, and fund research and development spending in order to develop a defense industrial base.

Determining the appropriate defense industrial base is difficult. The defense ministry must decide on (1) the number of different systems required and the quality and quantity of each, (2) the extent to which it can trust allies to collaborate in production or to provide imports, in particular whether they would supply in conflict, and (3) the potential export market for the systems, the degree to which exports are taxed or subsidized, and the security consequences of those exports. All these judgments have to be made subject to a budget constraint. In fact, for most countries, their budget constraint is such that they cannot afford the massive R\&D required to develop and produce major weapons systems. There are a few large producer countries and the remainder import all their major weapons systems. Even the largest producer, the U.S., has to import some systems. Dunne (1995) discusses the defense industrial base and Dunne, et al. (2007) provide a model of the process.

The high fixed R\&D costs mean that average cost fall sharply with each further unit produced, so major weapons producers can gain economies of scale and the minimum efficient scale is large relative to the size of the market. Having a single producer for any type of system takes advantage of this economy of scale but having multiple competing firms may help keep down prices and stimulate innovation. This tension between the benefits of scale and the benefits of competition has been a central defense industrial policy dilemma for the last 50 years. Other dilemmas include the fact that technical advances raise costs and this interacts with constrained budgets to mean that fewer units can be produced in each generation, further raising unit costs. One response is to keep the equipment in service longer. Thus, the B52 aircraft introduced in the 1950s, are still in service, meaning that technological jumps between generations are larger, introducing further uncertainty.

One relatively new issue in regulation is how national governments should treat corruption in defense contracts, given that payment of bribes seems common in the international arms trade. Traditionally, governments ignored such payments, but anti-corruption activity is increasing for various reasons. There have been a range of allegations about bribery by BAE and in 2006 the U.K. government stopped a Serious
Fraud Office investigation into allegations that BAE paid bribes over the al-Yamamah contract with Saudi Arabia. In 2010, BAE paid criminal fines to the U.S. and U.K. authorities over alleged corruption. In early 2013, EADS was being investigated over allegations that its Cassidian subsidiary paid bribes in Austria to sell Eurofighter Typhoon aircraft and that its U.K. subsidiary, GPT Special Projects, bribed Saudi officials over a project to supply military communications equipment. In an October 2012 report by Transparency International, EADS ranked well below peers like BAE for vigilance against corruption, and in November 2012 it commissioned an external review of its compliance systems. Giuseppe Orsi, the chief executive of Finmeccanica, was arrested in 2013 on alleged corruption charges.

Traditionally, because the state, which had strong national preferences, was the customer, major countries largely relied on their domestic defense industries. Unlike most manufacturing industries, which went multinational, the arms industry remained national. Smaller countries which could not afford the large fixed costs imported major weapons systems. With the fall in demand, the ability of even the major countries to maintain a domestic defense industrial base was called into question, making them more willing to import. As a result, domestic and foreign weapons came to be regarded as closer substitutes than in the past.

\section{Consolidation}

The impact of industrial policy is illustrated by the U.S. merger wave which started in 1993 when then-Deputy Secretary of Defense, William Perry, told a dinner meeting of defense industry executives — dubbed "the last supper" - that there were too many companies. The wave ended in 1997 when the Pentagon decided it had gone far enough and blocked the merger of Lockheed Martin with Northrop Grumman. As of early 2013, there is no indication that the U.S. Department of Defense would support major mergers, but that may change if cuts start to bite.

In Europe, the merger process came later and was more complicated, but produced four large groups-BAE, EADS, Thales, and Finmeccanica-and many joint ventures. For instance, BAE and EADS collaborate on the production of the Eurofighter Typhoon and as owners with Finmeccanica of the MBDA missile producer. The collaboration extends beyond Europe, and there are longstanding links between the state-owned French aero-engine company SNECMA and GE of the U.S. SNECMA is now part of Safran, formed from the merger of SNECMA with the security company SAGEM in 2005.

The earlier consolidation process had involved Daimler Aerospace, DASA, in talks to merge with then-BAe during 1998. But when BAe instead acquired the defense divisions of GEC to form BAE Systems in 1999, Daimler merged DASA with Aerospatiale-Matra and CASA to form the transnational EADS. BAE was a shareholder in EADS by virtue of its 20 percent stake in Airbus, but disposed of this holding in 2006 to concentrate on defense. Daimler was subsequently a reluctant 
shareholder in EADS. The multinational Thales was formed in 2000 when the French company Thompson CSF acquired Racal's U.K. defense operations. In early 2013, the French state held 27 percent of Thales. In 2009, the largest private shareholder in Thales - Alcatel-Lucent-sold its stake to Dassault which now holds 26 percent of the shares and is the dominant influence on Thales. Finmeccanica completely acquired the helicopter manufacturer Agusta-Westland in 2004. Caruso and Locetelli (2013) review Finmeccanica and the Italian defense industrial base.

\section{Options for the industry}

Faced with reductions in military demand, arms firms have five options on a civilian-military axis: Convert, diversify, divest, cooperate, or concentrate. For the first of these, the conversion of plants producing military products into ones producing civilian products,.there are very few historical examples of a successful conversion strategy of this sort. Conversion of plants is difficult because the markets and cultures are so different in the military and commercial arenas. For instance, whereas the military emphasis is on performance maximization, the commercial emphasis is on cost minimization. In addition, defense companies are specialists in selling to a single bureaucratic political customer, which is very different to selling to a mass market.

Diversification involves the development of new commercial activities either through the organic growth of new businesses or the acquisition of existing businesses. This is more likely to work if the firm can build synergies between the military and civil parts of the business. Probably the most impressive piece of diversification was the U.K. defense company Racal, building the Vodaphone mobile phone business in the late 1980s, which it then spun-off. There are far more examples of unsuccessful diversification. For example, after privatization, British Aerospace bought a construction company, a property company, and a car company. There were plausible tactical justifications for each, but they did not work and BAe divested them and became more focused as a defense company. Finmeccanica, which has been making losses, is trying to divest its energy and transport divisions.

Where competition regulations made it possible, divesting defense divisions by selling them to competitors is in many cases an attractive proposition, since they are worth more to the competitor who gains increased monopoly power. In the U.S. during the 1990s General Dynamics was an early exponent of this strategy and initially shrank itself rapidly and profitably. In the U.K., GEC sold its defense divisions to BAe in 1999 and turned itself into a purely commercial company, Marconi, which subsequently failed.

Cooperation has always been common, and aerospace and defense companies use joint ventures, collaboration, and strategic alliances to gain the benefits of scale without losing independence. The final strategy is concentration on the core weapons business. A group of companies have focused on defense, acquiring the defense divisions others divested, and often shedding civil activities. The concentrating companies, like BAE, have tended to diversify into other weapons systems to allow them to market a full product range, rather than into civil work. For instance, BAE sold its shareholding in Airbus in 2006 to concentrate on defense.

\section{BAE Systems and EADS}

The issues that arose in the proposed merger of BAE and EADS are informative. The fact that the Dassault Rafale fighter aircraft had beaten the Eurofighter Typhoon (produced by EADS, BAE Systems, and Finmeccanica) for a large Indian contract in 2012 prompted EADS and BAE to discuss merging. The discussion leaked in September 2012, and there was an intense international debate before the merger was blocked in October by the German government, apparently because there would be no German head office. A merger would have created the world's largest arms producer. On SIPRI (2012) figures for 2010, BAE+EADS would have arms sales of almost \$50bn, compared with \$36bn for Lockheed Martin.

Ian King and Tom Enders, the chief executives of BAE and EADS, respectively, said in a joint article that the merger discussion did not reflect weakness because the two firms "are both strong businesses with clearly defined strategies that have enabled them to make progress in the past five years, and which would take them forward as independent companies" (Financial Times, 1 October 2012). (Tom Enders, the German CEO of EADS, had been involved in the attempt to merge DASA with BAe before the formation of EADS.) However, both companies are perceived to have certain weaknesses. BAE was seen as too dependent on defense, which looks to be a declining market. EADS was seen as too dependent on the political influence of the French and German states. Indeed, EADS has argued that state involvement in its ownership had inhibited its efforts to make a big acquisition in the U.S. and may have hindered its bid to win a U.S. military tanker order. King and Enders hoped that a merger would reduce both weaknesses: To create a normal company without state influence and equally balanced between civil and defense work.

EADS is registered as a company in the Netherlands. France and Germany each hold 22.35 percent of the company, one through the Lagardère company and the French state, the other through Daimler. The Spanish state has 5.45 percent. Both Daimler and Lagardère are reluctant owners, but are forced to maintain their position to keep the German and French holdings equal. There have been recurrent rumours that French and German government holdings would each be reduced to 12 percent.

The EADS Vision 2020 Strategy, set out in 2007 by Louis Gallois, Tom Ender's predecessor as CEO, was to turn EADS's revenue stream into something similar to Boeing's, with half coming from civil aircraft and half coming from defense, which was seen as less cyclical. The EADS defense subsidiary, Cassidian, the German-based defense business, is relatively small. EADS also produces the troubled A400M military transport and a range of military helicopters through Eurocopter. Boeing and EADS both produce military aircraft, electronics, missiles, and space equipment. BAE 
has a much wider defense portfolio, also including military vehicles, artillery, small arms and ammunition, and warships, both surface and submarine. Thus the BAE defense portfolio has a less good fit with aerospace than that of Boeing or EADS.

Many were skeptical of the merger on commercial grounds given the difficulty of successfully merging two very different companies and the fact that academic studies indicate that most merger and acquisition activity destroys value. BAE's past history of deal-making does not inspire confidence. Many had questioned the wisdom of its recent U.S. purchases, its 2006 sale of its Airbus stake, or further back its acquisition and divestment of a car company, a construction company, and a property company.

The shareholders in the two companies chose to own them for rather different reasons. For instance, BAE pays a much higher dividend than does EADS, and BAE's largest shareholders expressed opposition to the deal. There were concerns that the proposed 60:40 split did not reflect the true value of the companies and this caused a sharp decline in EADS's share price after the merger announcement.

While there were commercial questions about the wisdom of the merger, and questions about what the merged company would be called, the main arguments tended to be political rather than commercial. Merger would have required approval by the governments of France, Germany, Spain, the U.K., and the U.S. (since BAE produces so much in the U.S.) and of the European Commission under EU Competition Law. One tension in the case for the merger was that commercial weaknesses were political strengths, and vice versa. For instance, because the companies did not overlap very much, there were few economic gains from synergies or rationalization, a commercial disadvantage, but there would consequently be few losses of jobs or sovereignty, a political advantage.

The merger would have had significant implications for the future structure of the European defense industrial base, and many were surprised that it was the German government that vetoed the merger and that the French and British governments were more supportive. Successive U.K. governments have been rather relaxed about consolidation, for instance allowing Thales to take over Racal, preferring to leave the evolution of the industry to market forces. The situation in France has been more complex. While the French direction générale de l'armement (DGA)—France's arms procurement agency-has tried to encourage consolidation and rationalization, progress has been slow. French military industrial politics can be quite complex. Although the French state has a 27 percent shareholding in Thales, Dassault, with a 26 percent stake, effectively controls Thales. There have been recent changes in management at both Thales and Dassault. EADS had wanted to acquire Thales, but was stopped by the French state. In what the Financial Times (16 February 2012, p. 19) calls “one of those strange quirks of French industry,” EADS owns 46 percent of Dassault Aviation but has no control. Thus it might make more sense for EADS to take control of the defense part of Dassault and Thales. This might stop European aerospace firms competing against each other as they did in the Indian bid where the Eurofighter Typhoon lost out to Dassault's Rafale. There was also speculation in 2012 about a merger of Dassault, Thales, and Safran into "France Aerospace," speculation which Dassault dismissed. The evolution of the European defense industry is likely to be interesting and controversial.

\section{Conclusion}

In the absence of new security threats, measures to reduce deficits and debt in western countries are likely to put downward pressure on their military expenditure. When this last happened at the end of the cold war, concentration in the defense industry increased substantially, then fell again in the early years of the 21st century when military expenditure increased. With falling military spending, it is likely that concentration will increase again, but the process will be complicated by national defense industrial policies in Europe, making prediction difficult.

Notes

Ron Smith is an economics professor at the Department of Economics, Mathematics, and Statistics, Birkbeck College, University of London, London, U.K. He may be reached at<r.smith@econ.bbk.ac.uk>.

\section{References}

Brauer, J. 2007. “Arms Industries, Arms Trade and Developing Countries.” Chapter 30 in T. Sandler and K. Hartley, eds. Handbook of Defense Economics. Vol. 2. Amsterdam: North-Holland.

Brzoska, M. 2007. "Success and Failure in Defense Conversion in the 'Long Decade of Disarmament'.” Chapter 34 in T. Sandler and K. Hartley, eds. Handbook of Defense Economics. Vol. 2. Amsterdam: North-Holland.

Caruso, R. and A. Locatelli. 2013. "Finmeccanica Amid International Market and State Control: A Survey of the Italian Defense Industry.” Defense and Peace Economics. Vol. 24, No. 1, pp. 89-104.

Dunne, J.P. 1995. “The Defense Industrial Base.” Chapter 14 in T. Sandler and K. Hartley, eds. Handbook of Defense Economics. Vol. 1. Amsterdam: North-Holland.

Dunne, J.P. 2009. "Developments in the Global Arms Industry from the End of the Cold War to the Mid-2000s,” pp. 13-37 in R. Bitzinger, ed. The Modern Defense Industry: Political, Economic and Technological Issues. Westport, CT: Praeger.

Dunne, J.P., M. Garcia-Alonso, P. Levine, and R.P. Smith. 2007. "Determining the Defense Industrial Base.” Defense and Peace Economics. Vol. 18, No. 3, pp. 199-222.

Hartley, K. 2007. “The Arms Industry, Procurement and Industrial Policies.” Chapter 33 in T. Sandler and K. Hartley, eds. Handbook of Defense Economics. Vol. 2. 
(c) www.epsjournal.org.uk - Vol. 8, No. 1 (2013)

Amsterdam: North-Holland.

SIPRI Yearbook. Various years. Armaments, Disarmament and International Security. Oxford, UK: Oxford University Press for Stockholm International Peace Research Institute.

Smith, R.P. 1990. "Defense Procurement and Industrial Structure in the UK." International Journal of Industrial Organization. Vol. 8, No. 2, pp. 185-205.

Smith, R.P. 2001. “The International Arms Industry.” World Economics. Vol. 2, No. 3, pp. 155-166. 